\title{
Studies on the toxicity of 2-Methyltetrahydrofuran on the histopathology of gills of African catfish Clarias gariepinus
}

\section{S. B. Zade}

Department of Zoology, R.T.M. Nagpur University, Nagpur (MS), India

D. M. Agase*

D. D. Bhoyar Arts and Science College Mouda, Dist. Nagpur (MS), India

A.M. Nagwnshi

Department of Zoology, R.T.M. Nagpur University, Nagpur (MS), India

H. N. Nenwani

Department of Zoology, R.T.M. Nagpur University, Nagpur (MS), India

S. N. Qureshi

Department of Zoology, R.T.M. Nagpur University, Nagpur (MS), India

H. Jagyasi

Department of Zoology, R.T.M. Nagpur University, Nagpur (MS), India

${ }^{*}$ Corresponding author. E-mail: sbt.durgesh@gmail.com

\begin{abstract}
In the present study, investigation were carried out on gills of African cat fish Clarias gariepinus exposed to sub lethal concentrations $(80 \mathrm{mg} / \mathrm{ml}, 400 \mathrm{mg} / \mathrm{ml}$ and $800 \mathrm{mg} / \mathrm{ml})$ of 2 -Methyltetrahydrofuran for 10 days. Lesions were observed in gills tissue of treated fish for long term exposure to Methyltetrahydrofuran (2MTHF). The occurrence and degree of alteration were positively related with the concentration of 2MTHF. Histological examination of the gills of fish treated with $80 \mathrm{mg} / \mathrm{ml}$ of $2 \mathrm{MTHF}$ for 10 days showed architectural loss, necrosis and desquamation of epithelial layer. Histological examination of the gills of fish treated with $400 \mathrm{mg} / \mathrm{ml}$ of $2 \mathrm{MTHF}$ for 10 days showed architectural loss, necrosis and mild vaccuolation. The gill filament exhibited telangiectesis, disorganisation of secondary gill lamellae and complete vaccuolation of gills treated with $800 \mathrm{mg} / \mathrm{ml}$ of 2MTHF for 10 days. The study indicated that 2MTHF had marked effects on the cytoarchitecture of the gills of $C$. gariepinus. The degree of vaccuolation and necrosis were positively related with the concentration of $2 \mathrm{MTHF}$
\end{abstract}

Keywords: Gill lamellae, 2-Methyltetrahydrofuran (2MTHF), Nacrosis, Telangiectesis, Vaccuolation

\section{INTRODUCTION}

At present a large number of pollutants and waste are eliminated to the environment because of human activities. A wide range of man-made chemicals used for several industrial and household activities have been shown to disturb normal physiology and endocrinology of aquatic organisms (Balabanic et al., 2011, Rhind., 2009). In the present study, investigation were carried out on gills of African cat fish (Clarias gariepinus) exposed to 2-MTHF. 2-MTHF is mainly used as a higher boiling substitute for tetrahydrofuran and used in secondary lithium electrodes, as a component in alternative fuels. This compound is widely used as a reaction medium for Grignard and metal hydride reactions, in the fabrication of articles for packaging, transporting, and storing of foods, as a solvent for dyes and lacquers and as a chemical intermediate in polymerization solvent for fat oils, unvulcanized rubber, resins, and plastics. It is also

\section{Article Info}

DOI:10.31018/jans.v10i2.1775

Received: December 31, 2018

Revised: April 9, 2018

Accepted: May 15, 2018

\section{How to Cite}

Zade, S.B. et al. (2018)

Studies on the toxicity of 2Methyltetrahydrofuran on the histopathology of gills of African catfish Clarias gariepinus. Journal of Applied and Natural Science, 10(2): 765 - 769 an indirect food additive when it is in contact with the surface of articles intended for use in food processing. It is discharge form power plants, plastic industries and electrolyte industries (Aycock et al.,2007, (Man et al., 2003).

Its high toxicity, lower sensitivity to photooxidation, high persistence in water and low molecular weight, 2-MTHF accumulates rapidly in aquatic animals and affects normal vital functions. It is generally found in greater concentrations in fish tissues which are direct and continuous contact such as gills. 2-MTHF in fish organs are not directly responsible for the death of the organism, but sublethal concentrations may affect its functionality and normal physiology by damaging biological structures (Liqun et al.,2014). Tetrahydrofuran has been reported as carcinogenic effects in rat and mice (Chhabra et al., 1998). Its mutagenic effects have been reported in Chinese hamster ovary cells and in mouse bone marrow cells 
(NTP., 1998). Histological changes associated with different derivatives of tetrahydrofuran and tetrahydrofuran like chemicals in fishes have been studied by many authors ( Leino et al.,1987. Roy et al.,1991. Tilak et al., 2001). There are no articles available on gill histology of fish exposed to 2 -MTHF. Moreover, studies on the histopathology of different fish organs exposed to other contaminants are often carried out with freshwater or brackish-water species (El-Sayed et al. 1995) (Dwivedi et al. 1997).

The objective of the present study was to describe the effects of 2-Methyltetrahydrofuran on the gills of African catfish Clarias gariepinus, assessing alterations in the gills function in relation to concentration. To our knowledge, this is the first investigation on alterations of gill morphology in African catfish Clarias gariepinus exposed to sublethal concentrations of 2-MTHF.

\section{MATERIALS AND METHODS}

The fresh water African catfish, C. gariepinus, was selected for the present study because of its availability from local tanks or market and or its convenient size. All the fishes used in the present study were brought from the local market. The body weight of fish ranged between $250-350 \mathrm{gm}$ and their length varied between $30-37 \mathrm{~cm}$. The fish were mainained in glass aquarium containing 50 liter of tap water, under normal conditions of light and temperature. The fishes were acclimatised for one weak by keeping 6 fishes in each aquarium prior to their use in the experiment.

In the present study, the chemical 2-MTHF (Product code: 99983) was purchased from SRL laboratories Pvt. Ltd (CAS No. : 96-47-9) (where $0.855 \mathrm{gm} / \mathrm{ml}$. The four aquaria were taken filled with 50 liter tap water, and 6 fishes were kept in each aquarium. The fishes in the one aquarium were treated as control and other three aquarium exposed with three different concentrations group $(80 \mathrm{mg} / \mathrm{ml}, 400 \mathrm{mg} / \mathrm{ml}$ and $800 \mathrm{mg} / \mathrm{ml}$ respectively). The control and treated fishes were dissected out for histopathological examination. For microscopic examination, surviving fishes of each group were removed and dissected. Small pieces of the gills tissue were taken and immediately fixed in Bouins fixative (Saturated aqueous picric acid : 75 $\mathrm{ml}, 40 \%$ aqueous formaldehyde: $25 \mathrm{ml}$, glacial acetic acid: $5 \mathrm{ml}$ ). Fixed tissues were processed routinely for paraffin embedding technique. Embedded tissues were sectioned at $5 \mu$ in thickness and then stained with Eharlich hematoxylin (Haematoxylin crystals: 2gm, Absoute alcohol:100 $\mathrm{ml}$, glycerine: $100 \mathrm{ml}$, Glacial acetic acid:10ml, Distilled water:100 ml, Alum in excess) and Eosin stain (Eosin powder: $1 \mathrm{gm}, 70 \%$ alcohol: $100 \mathrm{ml}$.) and mounted in DPX. The slides were then observed Light microscope (Trinocular Compound Microscope SF40T).

\section{RESULTS AND DISCUSSION}

The gill is made up of filaments of primary lamellae arranged in double rows. Secondary lamellae arise from these filaments. The secondary lamellae are lined by a squamous epithelium. Squamous epithelium is composed of pavement cells and non-differentiated cells. Below that epithelium are lamellar blood sinuses separated by pillar cells. Between the lamellae, the filament is lined by a thick stratified epithelium constituted by several cellular types, such as chloride, mucus and pavement cells (Jayachandran and Pugazhendy., 2009).

In the present investigation, no histopathological abnormalities were observed in the gills of the control fish (Fig. 1a, 2a and 3a). Lesions were observed in the gills tissue of Clarias gariepinus exposed to 2-MTHF. The occurrence and degree of alterations were positively related with the concentration of 2-MTHF. The histological changes observed in the 2-MTHF exposed and control fishes are shown in Table 1.

Histological examination of the gills of fish exposed to $80 \mathrm{mg} / \mathrm{ml} 2-\mathrm{MTHF}$ for 10 days showed mild architectural loss, necrosis and desquamation of epithelial (Fig:1b). Histological examination of the gills of fish exposed to $400 \mathrm{mg} / \mathrm{ml} 2$ methyltetrahydrofuran for 10 days showed moderate architectural loss, necrosis, desquamation of epithelial, collapsed and curling of secondary lamellae, vaccuolation and mild telangiectesis (Fig. $1 c, 2 b, 3 b$ and $4 b, 4 c)$. Histological examination of the gills of fish exposed to $800 \mathrm{mg} / \mathrm{ml} 2$ methyltetrahydrofuran for 10 days showed severe architectural loss, necrosis, desquamation of epithelial, collapsed and curling of secondary lamellae, vaccuolation and telangiectesis (Fig. 1c, 2c and $3 \mathrm{c}$ ).

Histopathological results indicated that gill was the primary target tissue affected by 2 MTHF. Gills are generally considered good indicator of water quality being models for studies of environmental impact. Several other studies have shown similar

Table 1. Histological changes observed in the 2-MTHF exposed and control fishes.

\begin{tabular}{|c|c|c|c|c|}
\hline Histological changes & Control & $80 \mathrm{mg} / \mathrm{ml}$ & $400 \mathrm{mg} / \mathrm{ml}$ & $800 \mathrm{mg} / \mathrm{ml}$ \\
\hline Architectural loss and necrosis & & + & ++ & +++ \\
\hline $\begin{array}{l}\text { Desquamation of epithelial } \\
\text { Collapsed and curling of secondary lamellae }\end{array}$ & & $\begin{array}{l}+ \\
-\end{array}$ & $\begin{array}{c}++ \\
+++\end{array}$ & $\begin{array}{l}++++ \\
++\end{array}$ \\
\hline $\begin{array}{l}\text { Vaccuolation } \\
\text { Telangiectesis }\end{array}$ & & & $\begin{array}{c}++ \\
++ \\
+++\end{array}$ & $\begin{array}{c}++++ \\
+\end{array}$ \\
\hline
\end{tabular}




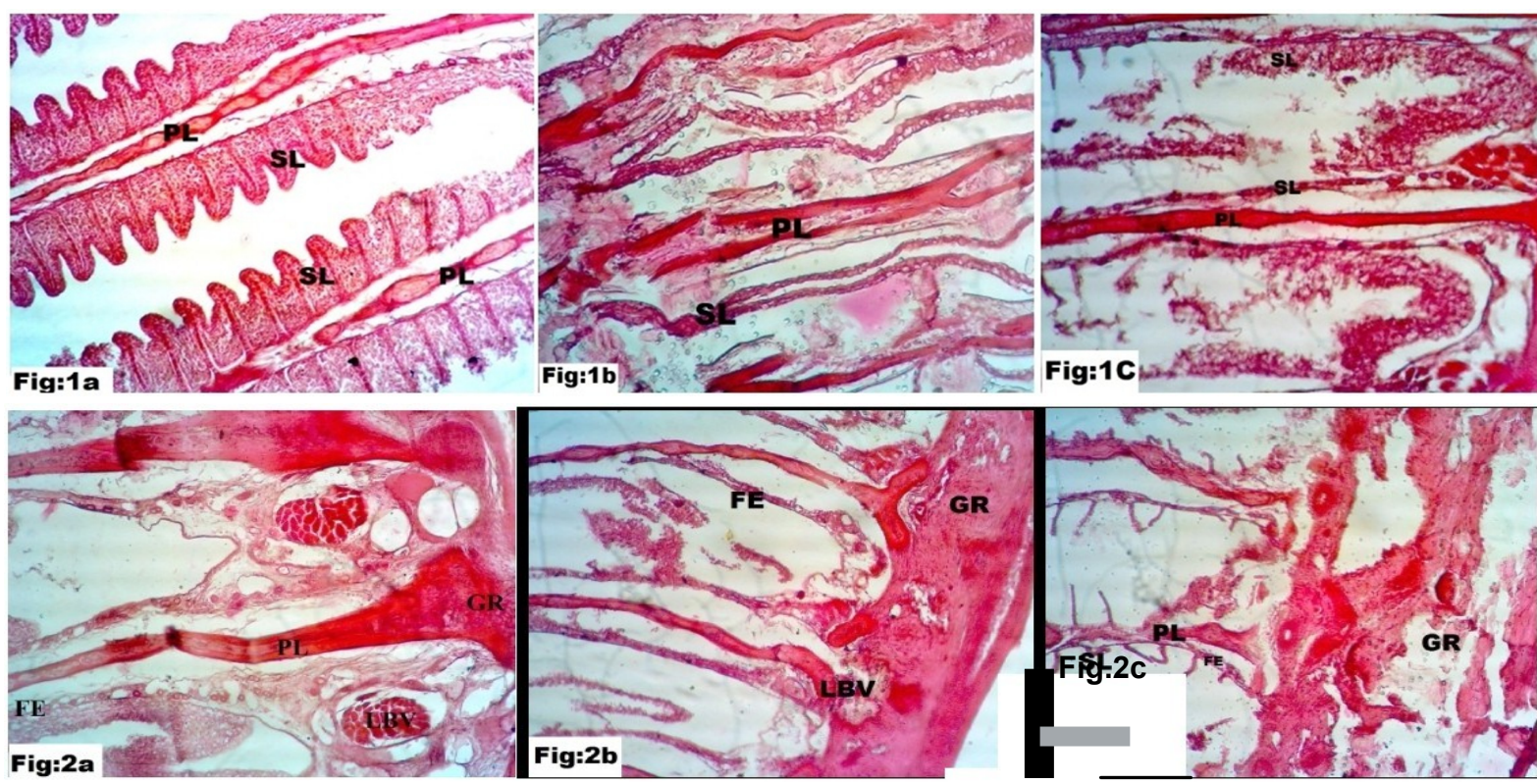

Primary lamellae= PL; Secondary lamellae=SL;Lamellar blood vessels=LBV; Filament Epithelial=FE: Gill Raker=GR; Fig. 1 a. L.S. of gill filaments of Clarias gariepinus from the control group showing intact Primary lamellae and Secondary lamellae; Fig.2a. L.S. of Gill arch of Clarias gariepinus from the control group showing intact Gill raker; Fig.1b. L.S. of gill filaments of Clarias gariepinus from the exposed group (80mg/ml) showing mild architectural loss, necrosis and desquamation of eqithelial layer; Fig1c. and 2b. L.S. of gill filaments of Clarias gariepinus from the exposed group $(400 \mathrm{mg} / \mathrm{ml})$ showing moderate architechtural loss, necrosis and desquamation of eqithelial layer and collapsed Secondary lamellae; Fig. 2c. L.S. of gill filaments of Clarias gariepinus from the exposed group $(800 \mathrm{mg} / \mathrm{ml})$ showing severe architechtural loss, necrosis, desquamation of eqithelial layer, collapsed and curling of Secondary lamellae.

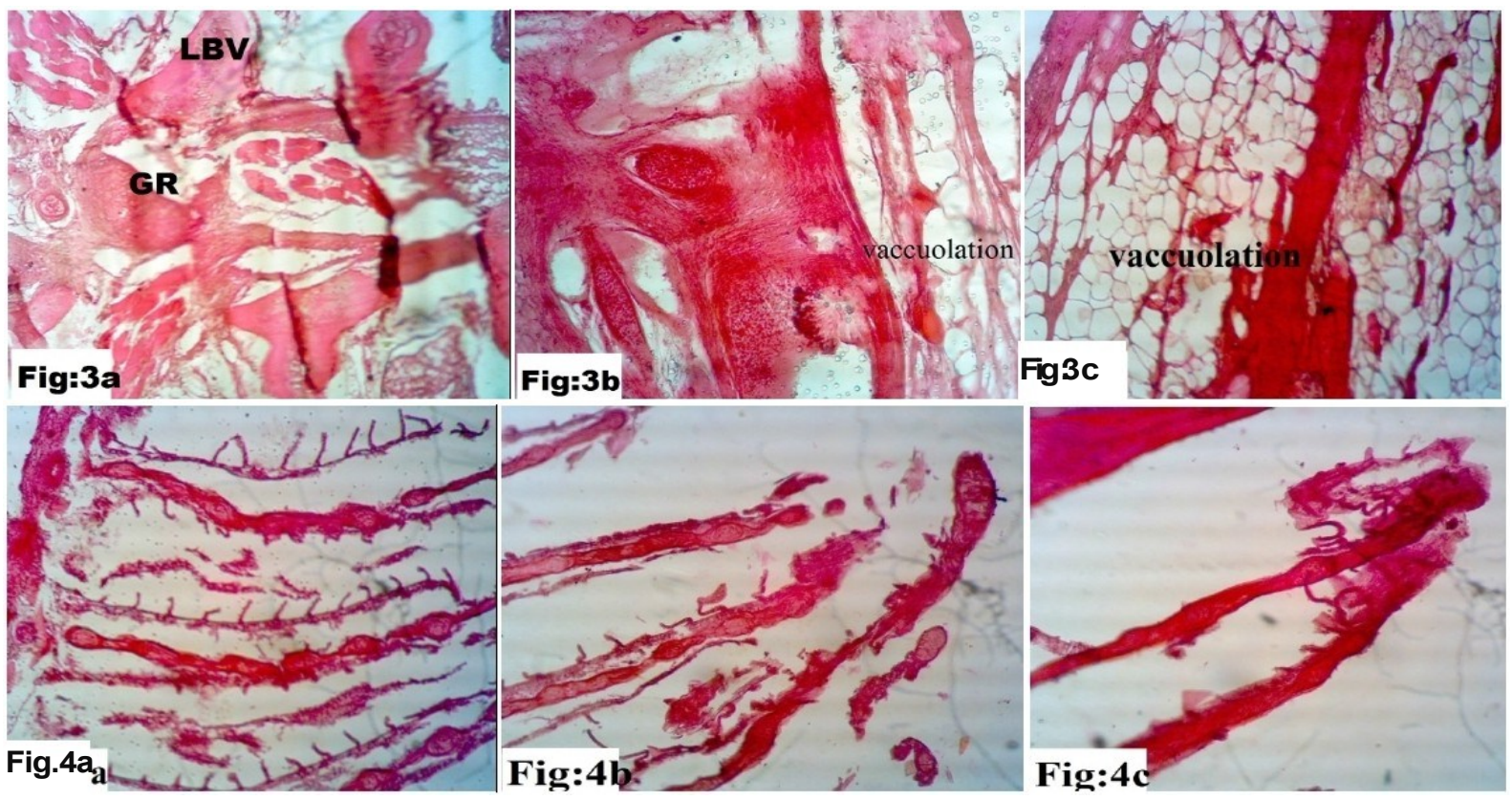

Primary lamellae= PL; Secondary lamellae=SL;Lamellar blood vessels=LBV; Filament Epithelial=FE: Gill Raker=GR; Fig. 3a. T.S. of gill of Clarias gariepinus from the control group showing Primary lamellae, Secondary lamellae, Chondrocytes, Lamellaer epith elialeell, Lamellar blood vessels, Gill raker; Fig.3b. T.S. of gill filaments of Clarias gariepinus from the exposed group $(400 \mathrm{mg} / \mathrm{ml})$ showing moderate Vaccuolation; Fig.3c. T.S. of gill filaments of Clarias gariepinus from the exposed group $(800 \mathrm{mg} / \mathrm{ml})$ showing severe Taccuolation; Fig.4a and $\mathbf{4 b}$. T.S. of gill filaments of Clarias gariepinus from the exposed group $(400 \mathrm{mg} / \mathrm{ml})$ showing collapsed and curling of secondary lamellae; Fig. 4c. T.S. of gill filaments of Clarias gariepinus from the exposed group $(400 \mathrm{mg} / \mathrm{ml})$ showing telangiectesis. 
effects in the gill architecture of fish have been exposure to Mercury (Gupta and Rajbanshi., 1995, Singh and Datta., 1996), zinc (Sharma and Sharma.,1991), pesticides (Tilk et al.,2001) Vijayalakshmi, and Tilak.,1996) as well as effluents from tannery (Sakthive.,1994) and textile mills (Dhanapakiam et al., 2004). Mucus extrusion, lamellar swelling, fused and reduced microridges, were observed in bluegill sunfish, Lepomis macrochirus to different sublethal concentrations of diazinon (Dutta et al., 1997). Histopathological changes observed were hemorrhage in the primary and secondary gill lamellae, degeneration and necrosis of epithelial cells, distortion of the secondary lamellae, disruption of epithelial cells from pillar cells. Shorter gill lamellae, fusion, complete destruction of lamella, increased vacuolation, irregular appearance of gill lamellae were observed in guppy Poecilia reticulate exposed to chlorpyrifos (De Silva and Samayawardhena, 2002). All the histopathological observation indicated that exposure to sublethal concentrations of $2 \mathrm{MTHF}$ caused destructive effect in the gill tissues of $C$. gariepinus. Gill histopathological alterations, observed in this study and findings from previous studies, could result in severe physiological problems, ultimately leading to the death of fish.

\section{Conclusion}

As a conclusion, the findings of the present histological investigations demonstrated a direct correlation between 2MTHF exposure and histopathological disorders observed in gills. After chronic exposure of $2 \mathrm{MTHF}$ to C.gariepinus at a concentration of $400 \mathrm{mg} / \mathrm{ml}$ and $800 \mathrm{mg} / \mathrm{ml}$ the fish exhibited the greatest amount of tissue damage architectural loss, necrosis, desquamation of epithelial layer, dilation of marginal vascular channels, and disorganization of secondary gill lamellae, shortening of secondary lamellae and telangiectesis. To our knowledge, this is the first investigation on alterations of gills morphology in African catfish Clarias gariepinus exposed to sublethal concentrations of $2 \mathrm{MTH}$.

\section{REFERENCES}

Aycock, G. and David, F. (2007). Solvent Applications of 2-Methyltetrahydrofuran in Organometallic and $\mathrm{Bi}$ phasic Reactions. J. Org. Proc. Res. Dev., 11:156159.

Balabanic, D., Rupnik, M. and Klemenc, A.K. (2011). Negative impact of endocrine-disrupting compounds on human reproductive health. J. Reproduction, Fertility and Development, 23: 403-416.

Chhabra, R.S., Herbert, R. A., Roycroft, J. H., Chou B. , Miller, R. A. and Renne, R. A. (1998). Carcinogenesis Studies of Tetrahydrofuran Vapors in Rats and Mice. J. Tox. Sci., 41:183-188.

De Silva, P. M. C. S., and Samayawardhena, L. A. (2002). Low concentrations of lorsban in water result in far reaching behavioral and histological effects in early life stages in guppy. Ecotox. Environ. Safe., 53: 248- 254.

Dhanapakiam, P., Ramasamy, V.K. and Sampoorani, R. (1998). A study on the histological changes in gills of Channapunctatus in Cauvery river water. J. Envrion. Biol., 19: 265-269.

Dutta, H. M., Munshi, J. S. D., Roy, P. K., Singh, N.K., Motz, L., Adhikari, S. (1997). Effects of diazinon on bluegill sunfish, Lepomis macrochirus, gills: scanning electron microscope observations. Exp. Biol. Online, 2: 1-11.

Dwivedi, H., Sari, R. and Wate, S. (1997). Long term effects of DI-aromatic hydrocarbon in catfish Heteropneustes fossilis. Journal of Ecobiology, 9: 247-254.

El-Sayed, N. K., Salem, S. A., Moursy, A. and Ibrahim, B. M. (1995). Acute and chronic toxicity of some aromatic hydrocarbons on Tilapia zillii. Bulletin of the National Institute of Oceanography and Fisheries, 21: 613-630.

Gupta, A.K., Rajbanshi, V.K. and J. Environ (1995). Histopathological lesions in the selected tissues of Cirrhinus mrigala (Ham.) fingerlings exposed to a sublethal concentration of mercury Biol.,16 (1): 3336.

Jayachandran, K. and Pugazhendy, K. (2009). Histopathological changes in the gill of Labeo rohita (hamilton) fingerlings exposed to atrazine. J. Sci. Res., 4:219-221.

Leino, R.L., P. Wilkinson and J.G. Anderson. (1987). Histopathological changes in the gills of pearl dace semotilus margarita and fathered minuows pimephales promelas, from experimentally acidified Canadian lakes. Can. J. Fish Aqucat. Sci., 44: 126134.

Liqun, X., Hongling. L., Xiaowei, Z., Markus, H., John, P. and Hongxia, Yu.(2014). A comparison of statistical methods for deriving freshwater quality criteria for the protection of aquatic organisms. Environ Sci Pollut. Res., 21:159-167.

Man, He., Zhou, Da-Qing, Ge, Hong-Li, Huang, Mei-Yu, and Jiang Ying-Yan (2003).Catalytic Behavior of Wool-Rh Complex in AymmetricHydrogenation of 2Methyl Furan. Polymers for Advanced Technologies 14: 273-277.

NTP (1998). Toxicology and Carcinogenesis Studies of Tetrahydrofuran (CAS No. 109-99-9) in F344/N Rats and B6C3F1 Mice. Natl Toxicol Program Tech Rep Ser.,475:1-244.

Rhind, S.M.(2009). Anthropogenic pollutants: a threat to ecosystem sustainability. J. Phil. Trans. R. Soc. B., 364:3391-3401.

Roy, P.K. and J.S. Datta Munshi, 1991. Malathion induced structural and morphometric changes of gills of a freshwater major carp Cirrhinus mrigala (Ham.). $J$. Environ. Biol., 12(1): 79-87.

Sakthivel, M. (1994). Sublethal effects of tannery and textile mill effluents on gill structure, respiration and bioconcentration of Chromium in Cyprinus carpio (Linnaeus). J. Environ. Poll. 1(3-4): 83-88.

Sharma, A and M.S. Sharma (1991): Histopathology of zinc to developing. Lebistes reticulatus (Peters) and Cyprinus carpio (Linnaeus). Poll-Res. 10(3): 183-188.

Singh, A.N. and Datta Munshi. (1996). Scanning electron microscopic evaluation of the effects of short and long term exposure of copper and mercury on the gills of Channa punctatus (Bloch) J.S.: J. Freshwater Biol., 8 (1): 51-55. 
Zade S.B. et al. / J. Appl. \& Nat. Sci. 10 (2): 765 - 769 (2018)

Tilak, K.S., K. Veeraiah and K. Yacobu, 2001. Studies of histopathological chanes in the gill, liver and kidney of Ctenopharyngodon idellus (Valenciennes) exposed to technical fenvalerate and EC20\%. Poll.
Res., 20(3): 387-393.

Vijayalakshmi, S and Tilak K.S. (1996). Effect of pesticides on the gill morphology of Labeo rohita. J. Ecotoxicol. Environ. Monit. 6: 59-64. 